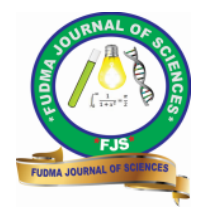

FUDMA Journal of Sciences (FJS)

ISSN online: $2616-1370$

ISSN print: 2645 - 2944

Vol. 4 No. 3, September, 2020, pp 656-662

DOI: https://doi.org/10.33003/fjs-2020-0403-428

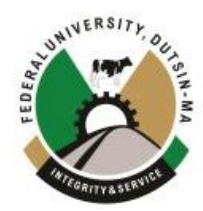

\title{
ASSESSING THE EFFECTS OF THE 2019 FLOOD IN YOBE STATE COMMUNITIES AND POSSIBLE MITIGATION APPROACH
}

\author{
*Gana A. H. and Salisu K. \\ Department of Biological Sciences, Yobe State University, Damaturu, Yobe State, Nigeria \\ *Corresponding Author's Email: Hassanagana09@gmail.com
}

\begin{abstract}
Flood is one of the natural disasters that cause serious damage to property, environment and human livelihood. Intergovernmental Panel on Climate Change (IPCC) reports over the years have indicated that climate related disasters will more than double between 2000 to 2050 in comparison to their occurrence in the $20^{\text {th }}$ century. It is evident that many communities around the world are becoming vulnerable to flood. Vulnerability is shaped by internal factors which (e.g poverty, age, weakness) these increase the degree of human exposure, and the external factors include (e.g susceptibility to climate change and socio-economic factors). It also depends on the sensitivity and adaptive capacity of a system to natural disasters. This study assessed the impacts of the 2019 flood in Yobe State, where data were obtained through Yobe State Emergency Management Agency (YOSEMA). YOSEMA is among the governmental organisations in the state that provides support and relief to flood victims and affected households. Secondary data was collected from YOSEMA (2019 flood report) to assess affected households and communities in the state. The 2019 flood events have affected over 5,000 households and had caused 4 deaths in the state. In this study, Holistic Flood Mitigation Approach was proposed to improve flood mitigation measures. This approach advocates for shifts from reactive approach (relief) to proactive approach (reduce risk). This can be conducted using the vulnerability indicators for the holistic approach. Further studies will be conducted to assess the level of household vulnerability in order to understand the recovery pace of communities.
\end{abstract}

Keywords: Disaster, Flood, Climate Change, Communities, Risk, Household, Vulnerability.

\section{INTRODUCTION}

Flood is becoming a serious problem and concern for most towns and cities in developing countries, especially in SubSaharan Africa (Nur and Shrestha, 2017). In recent years it had destroyed and damaged properties of inhabitants across the region and around the world. This has made people and communities in that part of the world more vulnerable to flooding and other weather events such as drought and storms (IPCC, 2007). Considering how climate is changing over the years, it is important to understand the vulnerability of communities and their inhabitants. Mitigation measures such as warning and rescue are the most common techniques used to decrease the adverse effects of such disasters in most vulnerable communities (Nur and Shrestha, 2017). This research explored how the 2019 flood in Yobe State has affected household. Communities' vulnerability depends mainly on its biophysical and socio-economic factors. Numerous research carried out over the years have not clearly defined flood/extreme flood (Kim, 2019). It is argued that flood does not have a clear definition. However, it can be defined as flood events that exceed the capacity of hydraulic structures, dams, reservoir embarkments and river dikes. Flood has the potential to destroy properties, depending on their magnitude (Kim, 2019).

Risk related to natural flood events have increased worldwide over the years, this is due to growing population, changing climate and development (Campell et al., 2019). Thus, there is need to invest in building community resilience i.e. to take risk reduction measures. This is to reduce impacts of flood and reduce losses caused by the disaster, having such measures will increase community recovery pace (Campell et al., 2019). However, the concept of resilience is complicated as most existing flood risk resilience frameworks are difficult to operationalize. They are mostly applicable at community level, but cannot be applied to other cases especially those with peculiarity (Keating et al, 2016).

\section{Vulnerability of Flood}

There has been different view on the concept vulnerability by scientists and social scientists. Where scientist agreed that it is the degree to which a system is unable to cope with adverse impacts of climate change related event (IPCC, 2007, 2014). On other hand is the probability of a hazard to occur and caused serious damage to a system (Brooks, 2003). Vulnerability is the occurrence of disaster which are caused by both climatic or non-climatic events (Lankao and Qin, 2011). This is due to a resulting interaction of exposures, sensitivities and capacities to withstand such conditions (Adger, 2000; Brooks 2003; and UNDP, 2007).

Vulnerability is shaped by internal factors which (e.g poverty, age, weakness) these increase the degree of human exposure, and the external factors include (e.g susceptibility to climate change and socio-economic factors). It also depends on the sensitivity and adaptive capacity of a system to natural disasters. Climatic variability with socioeconomic and cultural factors in communities increases exposures and sensitivities of individuals (including households), housing, land and infrastructure (Fussel, 2007). 
ASSESSING THE EFFECTS...

\section{FJS}

Impacts of Flood on Affected Area

Globally, natural disasters cause devastating effects on economies, livelihoods, agriculture, health and socioeconomic activities. According to United Nations Environment Program UNEP (2006), flood is one of the major environmental crises ravaging the universe in the $21^{\text {st }}$ century. Askew (1999), reiterated that floods cause about one third of most deaths, injuries and damages emanating from natural disaster. Okereke (2007) and Kolawole et al. (2011) highlighted the basic consequences of flood as; loss of human lives, submerging of residence and streets, inflow of sewage, municipal pollution and health hazards, traffic obstruction, aesthetic discoloring, cleanup cost and disruption of services, economic loss and damages to infrastructures. Flood causes serious damage to communities that are vulnerable such events, especially unprecedented ones. Hunger, famine, disease and epidemic outbreak are usually resultant impacts of flood (Mmom and Aifesehi, 2013). In Nigeria, effects of flood have displaced more people than any other natural disaster, it also caused more damage to home and properties (Etuonovbe, 2011).

\section{Flood Control Measures}

For centuries, several counter measures to prevent flood occurrence and damages has been deployed. Number of existing flood response systems were identified for extreme flood cases in Europe/USA (Kim, 2019). Table 1 below shows instructive flood control policies. It briefly explained objective of flood control strategies implemented in order to respond to extreme flood events. Basic water control policies promote river flood policies that include flood management, irrigation works and environment (Kim, 2019). In Europe, the Netherland, is a nation highly concerned with the water disaster prevention sector to mitigate extreme floods. The Netherlands has established water management policies, considering four types damages caused by flood include: casualties caused by lack of awareness about the flood, economic losses direct damages to buildings and infrastructures, and indirect damages

\section{Gana and Salisu}

caused by productivity decrease, and ecological damage (Terpstra and Gutteling, 2008).

The main purpose of Netherland's water management policies is preventing flood damages, flood- related water resources management and land spatial planning (Terpstra and Gutteling, 2008). The policy is an integrated operational programme which is essential for flood and water resource management. The Netherlands is particularly interested in retarding and retaining floods in middle-upper watersheds, managing flood plains to expand permeation spaces, expanding river areas to maintain extreme flood water levels and developing floodwarning methods for inhabitants (Terpstra and Gutteling, 2008).

The USA's flood policies were changed after the Mississipi River flood in 1993. This flood caused severe damage due to duration and distribution (Wilson et al., 2007). The extremeflood-related water management policies were implemented in the $21^{\text {st }}$ century in the USA which are strategically divided into two main policies: Water management policies (whose purpose is reducing the national vulnerabilities regarding flood damage or risk). Environmental policies (whose purpose is to preserve the natural resources and functions of flood plains). Through these policies, vulnerabilities to extreme floods were reduced by empowering urban areas to respond. At the same time, infrastructures with risk of reaching their limit state in case of flood were also enabled to response to the standard design flood (Wilson et al., 2007). Also, the extreme flood response plan was implemented by reinforcing the existing flood damage minimizing (or preventing) structures principally in major cities and infrastructures, differentiating the water management safety level. As examined, existing flood management policies and extreme flood response cases are not far off from the known structural and non-structural flood management measures and techniques (Wilson et al., 2007).

Table 1: Comparison of existing flood control measures in Europe \& USA

\begin{tabular}{|l|l|l|}
\hline & Europe & USA \\
\hline Flood characteristics & $\begin{array}{l}\text { Relatively uniform, rain falls and floods } \\
\text { throughout the year }\end{array}$ & Large regional variations \\
\hline Basic target & Flood, irrigation, environment & Flood, irrigation, environment \\
\hline Basic flood response policies & $\begin{array}{l}\text { Flood plain management (discharge } \\
\text { control, flood warning) }\end{array}$ & $\begin{array}{l}\text { Flood plain management (flood } \\
\text { communication and control, urban } \\
\text { storm water management) }\end{array}$ \\
\hline Flood measures & Flood plain management & Structural and Non-structural measures \\
\hline Flood regulations & Environmental law (1995) & $\begin{array}{l}\text { Flood plain management law, flood } \\
\text { control, administrative orders }\end{array}$ \\
\hline Comprehensive flood control planning & Flood plain management & $\begin{array}{l}\text { Flood plain management, flood damage } \\
\text { reduction }\end{array}$ \\
\hline
\end{tabular}

SOURCE: (Wilson et al., 2007). 


\section{FJS}

\section{METHODOLOGY}

During this research extensive literature materials were reviewed, where library catalogues, e-journals and secondary data were used. Yobe State Emergency

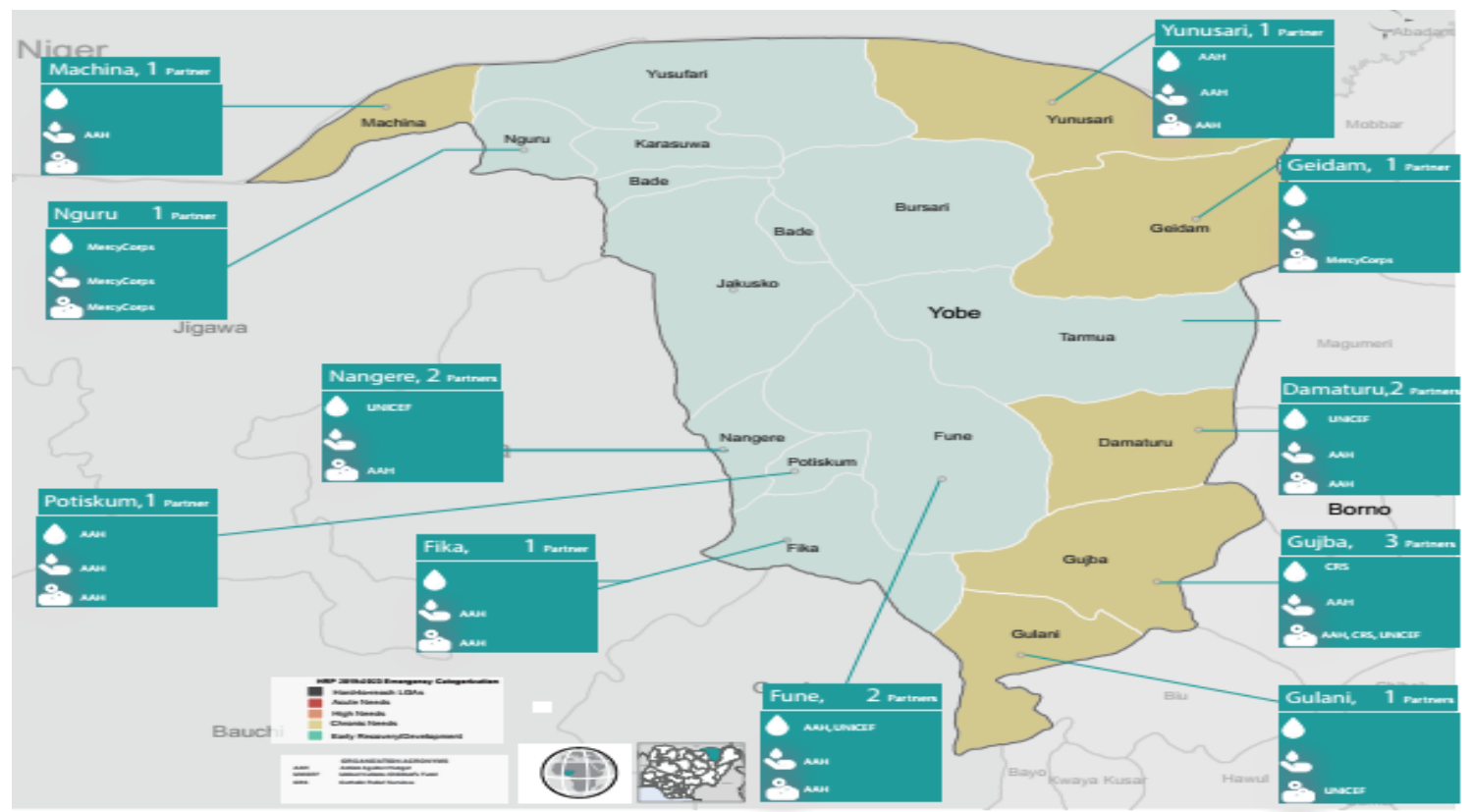

Fig 1: Map of Yobe showing the 17 Local Governments Areas (LGAs). Source: (YOSEMA, 2019).

Management Agency has provided its 2019 flood report during this study. Yobe State is among the 36 states of Nigeria and covers $47,153 \mathrm{~km}^{2}$. The state has 17 LGAs Bade, Bursari, Damaturu,Fika, Fune, Geidam, Gulani, Jakusko, Karasuwa, Nangere, Nguru, Potiskum, Tarmuwa, Yunusari, Gujba, Machina and Yusufari (Abdullahi et al., 2016). According to the National Population Commission (NPC), Yobe State had a population of 2,321,339 million people at the last (2006) census (NPC, 2006).

\section{Yobe State 2019 Flood Report}

Flood is one of the major disasters affecting Yobe communities, the state is located in the Sahel region of Nigeria where annual average rainfall is $<200 \mathrm{~mm}$ (Hassan et al., 2019; YOSEMA, 2019). Table 2 highlights the communities, households affected and interventions by government and NGOs. Of the 17 Local Government Areas (LGAs) in the state, 16 were affected by the 2019 flood, where 61 communities were the most impacted across these LGAs (YOSEMA, 2019). 
Table 2: Impacts of the 2019 flood on households in Yobe communities

\begin{tabular}{|c|c|c|c|c|c|}
\hline \\
\hline SN & $\begin{array}{c}\text { LOCAL GOV'T } \\
\text { AREA }\end{array}$ & COMMUNITY & HH AFFECTED & $\begin{array}{c}\text { HH } \\
\text { REACHED }\end{array}$ & $\begin{array}{c}\text { PARTNERS \& SUPPORT } \\
\text { PROVIDED }\end{array}$ \\
\hline \multirow[t]{6}{*}{1} & \multirow[t]{6}{*}{ Damaturu } & Kukareta & 269 & 200 & UNHCR \\
\hline & & Furi (A) & 88 & 88 & $\begin{array}{c}\text { AAH (Shelter kits/ Hygiene } \\
\text { Kits)/SEMA (NFI) }\end{array}$ \\
\hline & & Furi (B) & 28 & 28 & $\begin{array}{c}\text { AAH (Shelter kits/ Hygiene } \\
\text { Kits)/SEMA (NFI) }\end{array}$ \\
\hline & & Warsala & 34 & 34 & $\begin{array}{c}\text { AAH (Shelter kits/ Hygiene } \\
\text { Kits)/SEMA (NFI) }\end{array}$ \\
\hline & & Kalallawa & 91 & 91 & SEMA (F \& NFI) \\
\hline & & Usmanti & 137 & 137 & \\
\hline \multirow[t]{5}{*}{2} & \multirow[t]{5}{*}{ Bursari } & Fulatari & 22 & 22 & SEMA (F \& NFI) \\
\hline & & Metilari Community & 95 & 95 & \\
\hline & & Turban Gida & & & SEMA (F \& NFI) \\
\hline & & Ari Ganari Community & 62 & 62 & SEMA (F \& NFI) \\
\hline & & Dapchi Town & 110 & 110 & SEMA (F \& NFI) \\
\hline \multirow[t]{5}{*}{3} & \multirow[t]{5}{*}{ Geidam } & Hausari & 21 & 21 & SEMA (F \& NFI) \\
\hline & & Kolomari & 24 & 24 & SEMA (F \& NFI) \\
\hline & & Ashekri & 43 & 43 & SEMA (F \& NFI) \\
\hline & & Kolori & 112 & 112 & SEMA (F \& NFI) \\
\hline & & Gumsa & & & \\
\hline \multirow[t]{2}{*}{4} & \multirow[t]{2}{*}{ Gulani } & Gagutto & 73 & & \\
\hline & & Bagardo & 46 & & \\
\hline \multirow[t]{2}{*}{5} & \multirow[t]{2}{*}{ Fika } & Ngalda & 141 & 141 & SEMA (F \& NFI) \\
\hline & & Godowoli & 198 & 198 & SEMA (F \& NFI) \\
\hline \multirow[t]{7}{*}{6} & \multirow[t]{7}{*}{ Yusufari } & Tulo-Tulo & 47 & 47 & SEMA (F \& NFI) \\
\hline & & Dilala & 62 & & \\
\hline & & Njibiri & 26 & & \\
\hline & & Bulturam & 13 & & \\
\hline & & GarinTudo & 16 & & \\
\hline & & Mastafari & 23 & & \\
\hline & & Mamaduri & 12 & & \\
\hline 7 & Yunusari & Dilala & 163 & & \\
\hline \multirow[t]{3}{*}{8} & \multirow[t]{3}{*}{ Fune } & Ngelzarma & 87 & 87 & $\begin{array}{l}\text { (SEMA) Food items and } \\
\text { clothing }\end{array}$ \\
\hline & & Gajenge & 48 & & \\
\hline & & Jajere & 78 & & \\
\hline 9 & Jakusko & Buduwa & 118 & & \\
\hline \multirow[t]{2}{*}{10} & \multirow[t]{2}{*}{ Nguru } & Nguru Central & 289 & & \\
\hline & & Nguru outside & 428 & & \\
\hline 11 & Machina & $\begin{array}{l}\text { Garanda, Kangarwa\& } \\
\text { Machina }\end{array}$ & $\begin{array}{c}343 \text { (Not } \\
\text { Validated) }\end{array}$ & & \\
\hline \multirow[t]{3}{*}{12} & \multirow[t]{3}{*}{ Nangere } & Nangere & $184 / 179$ & $184 / 179$ & $\begin{array}{c}\text { AAH (Shelter kits/ Hygiene } \\
\text { Kits)/SEMA (NFI) }\end{array}$ \\
\hline & & Kanda & 70 & 70 & SEMA (F \&NFI) \\
\hline & & Old Nangere & 185 & & \\
\hline 13 & Potiskum & Potiskum town & 986 & 150 & SEMA (F \&NFI) \\
\hline \multirow[t]{3}{*}{14} & \multirow[t]{3}{*}{ Tarmuwa } & Koriyel & $\begin{array}{l}204 \\
102 \\
\end{array}$ & $\begin{array}{c}104 \\
57 \\
102 \\
\end{array}$ & $\begin{array}{c}\text { IRC (Water storage } \\
\text { kits/Hygiene kits/Dignity } \\
\text { kits)/SEMA (NFI) }\end{array}$ \\
\hline & & Garga & 88 & & \\
\hline & & Jumbam & 21 & & \\
\hline 15 & Karasuwa & Wachakal & & & \\
\hline & & KarasuwaGarinGuna & & & \\
\hline & & Runfan Kara & & & \\
\hline & & Atta-Kura & 121 & & \\
\hline & & GarinLushe & & & \\
\hline & & Bukarti & & & \\
\hline & & Chumbusko & & & \\
\hline
\end{tabular}




\begin{tabular}{|c|c|c|c|c|c|}
\hline & & Bula Ngibiya & & & \\
\hline \multirow[t]{8}{*}{16} & \multirow[t]{8}{*}{ Bade } & Sugum & \multirow{8}{*}{397} & \multirow{8}{*}{200} & \multirow{8}{*}{ SEMA } \\
\hline & & Tagali & & & \\
\hline & & Abujan Amare & & & \\
\hline & & Dadin Kowa & & & \\
\hline & & Garin Lamido & & & \\
\hline & & Kabayo & & & \\
\hline & & Gapiyawa & & & \\
\hline & & Murza & & & \\
\hline & TOTAL & & 5,140 & 2778 & \\
\hline
\end{tabular}

Source: (YOSEMA, 2019)

4 deaths recorded, 3 in Jajere (mud wall fell on victims) 1 in Tagali (water). All injured victims referred to hospital have been treated and discharged.

\section{Adopted flood mitigation approach in Yobe State}

Flood threats in Nigeria is been controlled through number of actions which includes; physical intervention, legislation and policy formulation, flood awareness creation, engineering structures, relocation of human populations during flood and assisting victims with basic needs (Odunuga, 2008; Olorunfemi, 2011). It is important to include social welfare, health and victims' vulnerability during flood vulnerability risk assessment (Keating et al., 2016). Adopting spatial data for policy and planning to mitigate the impacts of flood is important. Other studies showed that most flood assessment mainly focus on the physical structures and damages caused by flood, instead of aspects such as economic damage, areas impacted and depth of the event (Masudet al., 2015).

Holistic approach to flood management, different aspects and components that include community's vulnerability, social investment, economic activities, areas of impacts and physical structures. Considering these components will reduce the cost and level of impacts before and after disaster. Table 2 showed that Potiskum LGA has the highest number of households $(\mathrm{HH})$ affected (986) by the 2019 flood in Yobe State, whereas Karasuwa LG was the least affected with (121 HH) LGA in the State. Other social and geographical aspects had play role in the impacts of the flood. For example, Potiskum has the highest population density in the state, Karasuwa is in the extreme northern part of the State where it is considered as arid land area. (Hassan et al., 2019).

Based on data provided by the Yobe State Emergency Management Agency (YOSEMA), the intervention only covered households affected. In order to have a comprehensive data for Holistic Flood Mitigation Approach (HFMA) there is need for detail on infrastructural impacts and other aspects. It is evident that shelter fit and clothing are most the support provided by both YOSEMA and NGOs, in some cases hygiene materials were also provided (YOSEMA, 2019). Unfortunately, the 2019 flood events in Yobe State had caused 4 deaths, it is vital to assess the communities that are prone to flood in the state.

\section{Holistic Flood Mitigation Approach}

In order to mitigate the increasing threat pose by flood to the communities of the state, a more comprehensive and robust approach is required. This study recommends the adoption of Holistic Flood Mitigation Approach (HFMA). The approach requires shift from reactive (crisis management) to proactive (Risk management). According to Wilhite (2005), adopting proactive measures to mitigate impacts of natural disasters reduce cost of recovery and management. It is expensive to use reactive measures and it also takes time for the community to recover due to lack of information, understanding and timely intervention. The proposed approach by this study requires assessment of communities considering all the indicators of flood vulnerability and management which include community's vulnerability, social investment, economic activities, areas of impacts and physical structures, environmental effects, exposure, sensitivity, timing and recovery pace of the particular community. All these can be assessed prior to the rainy season for policy and decision makers to act on before the disaster period. Policies can be reviewed to accommodate flood trend in the State to reduce impacts on communities, this is similar to the study of Wilson et al. (2007).

\section{CONCLUSIONS}

Flood is becoming a serious problem and concern for most towns and cities in developing countries, especially in SubSaharan Africa. In recent years, it had destroyed and damaged properties of inhabitants across the region and around the world. Due to its nature of impacts many communities in Yobe state are vulnerable to flood. Many countries over the years have been taking measures to mitigate the impacts of flood as it affects both structural and non-structural aspects of communities. Floods have causes billions of dollar worth of damage every year. According to the IPCC (2014a) the frequency of flood events around the world will increase with changing climate. Policy and holistic approach are required to mitigate the impacts of flood in communities around Yobe state. It is evident that the 2019 flood in Yobe State has affected $\sim 5,140$ households and 4 deaths in the state and the number will rise with increasing climate change impacts in the future. Thus, the need to adopt the proposed Holistic Flood Mitigation Approach in order to reduce the impacts of flood in Yobe State.

\section{FUTURE WORK}

A comprehensive study will be conducted to understand the level of household vulnerability using the flood vulnerability management components.

\section{REFERENCES}

Abdullahi, H.G., Fullen, M.A. and Oloke, D. (2016). Socioeconomic effects of drought in the semi-arid Sahel: a review. International Journal of Advances in Science Engineering and Technology, 1: 95-99. 
ASSESSING THE EFFECTS... FJS

Akintola, F.O. and Ikwuyatum, G.O. (2012). Issues in sustainable flood management in Nigeria. In Ivbijaro FA, Akintola FO. Editors; Sustainable Environmental Management in Nigeria. Ibadan, Oxford University publishers.

Anih, S.C. (2004). Effective survival measures against natural hazards in settled area. In L. Mbah, U. uchegbu and L. Muoghalu, management of environmental problems and hazards in Nigeria. England: Ashgate publishing limited.

Brooks, N. (2003). "Vulnerability, Risk and Adaptation: A conceptual framework". Tyndall Centre for Climate Change Research Working Paper 38:1-16.

Campbell, K.A., Finn L., Jeffrey C., Adriana K., Stefan, H. and Marilyn, M. (2019). First insights from the Flood Resilience Measurement Tool: A large-scale community flood resilience analysis. International Journal of Disaster Risk Reduction, (40): 101257.

Etuonovbe, A.K. (2011). The devastating effect of flooding in Nigeria, Hydrography and Environment, TS06J, Epworth, Zimbabwe.

Fussel, H.M. (2007). "Vulnerability: A generally applicable conceptual framework for climate change research". Global Environmental Change 17(2):155-167.

Hassan, A.G., Fullen, M.A. and Okole, D. (2019). Problems of drought and its management in Yobe State, Nigeria. Weather and Climate Extremes, 23: 100192.

Hinkel, J. (2011). "Indicators of vulnerability and adaptive capacity": Towards a clarification of the science-policy interface". Global Environmental Change 21(1):198-208

http://www.nihydro.gov.ng/wpcontent/uploads/2012/08/Amended=Report-of-The-NigerianHydrological-Services-Agency.pdf.

http://www.Un ocha.org

Intergovernmental Panel on Climate Change (IPCC). (2014a) Climate Change 2001-Impacts, Adaptation, and Vulnerability Summary for Policymakers and Technical Summary of the Working Group II Report. IPCC, Geneva, 89 pp.

IPCC, (2007). "Climate Change 2007: Impacts, Adaptation and Vulnerability. Contribution of working group II to the fourth assessment report of the intergovernmental panel on climate change". Eds. Martin L Parry, Osvaldo F Canziani, Jean P Palutikof, Paul J Van der Lindeen and Clair E Hanson: Cambridge University Press, Cambridge.

IPCC, (2014). Summary for Policy makers. In: Climate Change 2014: Impacts, Adaptation and Vulnerability. Part A: Global and Sectoral Aspects. Contribution of Working Group II to the Fifth Assessment report of the Intergovernmental Panel on Climate Change. Cambridge University Press, Cambridge, United Kingdom and New York, USA.

IPCC, (2007). "Climate Change 2007: Impacts, Adaptation and Vulnerability. Contribution of working group II to the fourth

\section{Gana and Salisu}

assessment report of the intergovernmental panel on climate change." (eds). Martin L Parry, Osvaldo F Canziani, Jean P Palutikof, Paul J van der Linden and Clair E Hanson: Cambridge University Press, Cambridge.

Ismawaty, Nur and Krishna, K. Shrestha (2017). An Integrative Perspective on community vulnerability to flooding in cities of developing countries. Urban Transitions conference, Shanghai, September 2016.

Keating, A., Campbell, K., Szoenyi, M., McQuistan, C., Nash, D. and Burer, M. (2016). Development and testing of a community flood resilience measurement tool. Natural Hazards Earth System Science, 77-101, https://doi.org/10.5194/nhess-17-772016.

Kelly, P.M. and Adger, W.N. (2000). "Theory and Practice in Assessing Vulnerability to climate Change and Facilitating Adaptation". Climate Change 47(4):325-352.

Kim, C.R. (2019). Framework of Extreme Flood Risk Management in the Typhoon Country Region.

Kolawole, O.M., Olayemi, A.B. and Ajayi, K.T. (2011). Managing flood in Nigerian cities: Risk analysis and adaptation options-Ilorin city as a case study. Archives of Applied Science Research 3: 17-24.

Lankao, Patricia, R. and Hua Qin (2011). "Conceptualizing urban vulnerability to global climate and environmental change". Environmental sustainability, 3(3):142-149.

Marcellinus, A.H. and Joseph, C.U. (2015). An assessment of the impact of flood events in Makurdi, Nigeria. Civil and Environmental Research. Vol.7:No. 10, 2015.

Masud, S., John, M. and Daniel F. R. (2015). "Adapting a holistic approach to flood management in the HawkesburyNepean region: complexities and perceptions of the agencies involved." Journal of Environmental Planning and Management, (ahead of-print):1-22.

Mmom, P.C. and Aifesehi, P.E. (2013). Vulnerability of Niger Delta Coastal Communities to Flooding. Journal of Humanities and Social Science, 10(6), 27-33. http://dx.doi.org/10.9790/0837-1062733.

NEMA (2013). Report on flood disasters in Nigeria. Abiya: Government press

Nkwunonwo, UC., Malcolm, W. and Brian, B. (2015). Flooding and Flood Risk Reduction in Nigeria: Cardinal Gaps. J Geogr Nat Disast, 5:136. Doi: 10.4172/2167-0587.1000136.

NPC (2006). Nigeria Population Commission Official Result for 2006 House and Population Census Figures. Bureau for National Statistics, Abuja, Nigeria.

Nur, I. and Shrestha, K. K. (2017). An integrative perspective on community vulnerability to flooding in cities of developing countries. Procedia Engineering, 198: 958 - 967.

Odunga, S. (2008). Urban land use change and the flooding in 
ASSESSING THE EFFECTS...

\section{FJS}

Ashimowu watershed, Lagos, Nigeria. University of Lagos, Nigeria.

Okereke, R.A. (2007). "Incidence of Flooding in Southern Nigeria". International Journal of Environmental Issues, Vol.5, (1-2), pp20-28

Olorunfemi, F.B. (2011). Managing flood disasters under a changing climate. Lessons from Nigeria and South Africa. NISER Research Seminar Series, NISER, Ibadan.

Terpstra, T. and Gutteling, J.M., 2008. Households' perceived responsibilities in flood risk management in the Netherlands. International Journal of Water Resources Development, 24(4), pp.555-565.

UNDP, (2007). "The other half of climate change: why

\section{Gana and Salisu}

Indonesia must adapt to protect its poorest people". United Nations Development Programme Indonesia, Jakarta.

UNEP, (2006). Gathering Storm: The Humanitarian Impact of Climate Change

Wilhite, D.A. (2005). Drought and Water Crises Science, Technology and Management Issues, CRC Press, Taylor and Francis, Boca Raton, Florida, USA

Wilson, S., and Temple, B., Million, M., Vazquez, C., Packard, M., et al (2007). The lack of disaster preparedness by public and its effect on communities. The internet Journal of rescue and Disaster Medicine.

Yobe State Emergency Management Agency (YOSEMA) (2019). Flood Report-Update. August 2019: PP 9. 